\title{
A Linguistic Analysis of the Dialect of Akçaabat: Women's Language
}

\section{Akçaabat Ağzının Dilbilimsel Analizi: Kadın Dili}

\author{
Hülya Misır' ${ }^{1}$
}

${ }^{1}$ Research Assistant, Ufuk University, Department of Foreign Language Education, Ankara, Turkey

ORCID: H.M. 0000-0003-4103-682X

Corresponding author/Sorumlu yazar: Hülya Misır,

Ufuk University, Department of Foreign Language Education, Ankara, Turkey

E-mail: hulya.misir@metu.edu.tr

Submitted/Bașvuru: 23.01.2020 Accepted/Kabul: 02.03.2020

Citation/Atıf:

Misir, H. (2020). A linguistic analysis of the dialect of Akçaabat: Women's language. TUDED 60(1), 373-388

https://doi.org/10.26650/TUDED2020-0001

\section{ABSTRACT}

The study aims to analyze the dialect of Akçaabat, the second biggest district of Trabzon province (Akçaabat İlçe Nüfus Müdürlüğü, 2016), spoken by female informants in an open marketplace called kadınlar pazart where women are vendors selling fruits and vegetables they produced. The historically established marketplace was selected intentionally to analyze the language use in diverse interaction and dynamic venues in such spaces as local markets. Oral communication among women coming from rural areas and working in the designated urban places for a day was recorded and transcribed. The presentation of the linguistic characteristics of Akçaabat dialect was realized through codification and categorizations of the transcribed speech data. Linguistic analyses of the dialect spoken by the women in the rural part of the district showed significant deviations with Akçaabat dialect from standard Turkish in terms of phonetics, morphophonology and morphosyntax. This study is significant in providing a snapshot of the 'living' representative dialectal features of Akçaabat dialect. It also contributes to the corpus of regional dialects with natural speech samples since dialectal data collected in various speech events are significant to observe preservation/transformation of the living dialects of a language.

Keywords: Akçaabat dialect, dialectology, women's language use, spoken corpus, standard Turkish

\section{ÖZET}

Bu araştırma, Trabzon'un en büyük ikinci ilçesi (Akçaabat İlçe Nüfus Müdürlüğü, 2016) olan Akçaabat'ta kadınlar pazarı adı verilen, kadınların kendi ürettikleri ürünleri sattıkları açık bir pazar yerinde gerçekleştirilmiştir. Akçaabat ağzı ile konuşan kadınların dil kullanım özelliklerini incelemek, çalışmanın ana amacıdır. Yerel pazar yerleri gibi çok çeşitli etkileşimlerin gerçekleştiği dinamik mekanlarda dil analizi yapmak amacında olan bu çalışma için özellikle tarihsel olarak önemli görülen bir pazar yeri seçilmiştir. Çalışmada, bir gün için kırdan kente gelip belirlenen bölgelerdeki bu pazarlarda çalışan kadınların sözlü iletişimi derlenmiş ve yazıya aktarılmıştır. Makalede, konuşma verilerinin kodlanıp sınıflandırılmasından sonra Akçaabat ağzının dilsel özelliklerine yer verilmiştir. İlçenin kırsal kesimindeki kadınlar tarafından konuşulan ağzın dilsel incelemeleri, Akçaabat ağzının standart Türkçeden sesbilgisel, biçimbilimsel sesbilim ve biçim-sözdizimsel açıdan önemli sapmalar gösterdiğini ortaya koymuştur. Bu çalışma Akçaabat ağzının 'yaşayan' temsilî ağız özelliklerini belgelendirmesi bakımından önemlidir. Bunun yanında, çeşitli diyaloglardan toplanan ağız verileri, bir dilin ağızlarının korunması ve dönüşümünün gözlemi için oldukça önemli görülmektedir. Bu çalışma doğal konuşma örnekleri ile bölgesel ağız derlemine katkıda bulunmayı amaçlamaktadır.

Anahtar Kelimeler: Akçaabat ağzı, diyalektoloji, kadın dil kullanımı, sözlü derlem, standart Türkçe 


\section{Introduction}

Dialect is a collection of forms of speech and varieties of articulation that in some cases distinguish or reflect social characteristics of a language area. It comprises of sound, structure, and meaning divergence from the standardized languages. The reason why the dialects are regarded as deviations or 'aberrations of a correct or standard form of language' is that it has usually been associated with substandard, low-status, and often rustic form of language that working class or groups lacking prestige such as peasants would use (Chambers \& Trudgill, 2004, p. 3). Dialects are formed by the folk language that is specific to certain settlements and people. In other words, the characteristics of a dialect are determined with the language spoken in a region. The basis of the dialect studies is the collection of the folk language. Therefore, the studies with oral data have an important place to understand the richness of the language and its historical process and to reveal the cultural treasures of a nation (Çolakoğlu, 2013; Uysal, 2009).

Both national and international scholars have scientifically endeavored to extract the elements of the Turkish dialects of Anatolia primarily in the 20th century. However, since Turkology as a science has been established late, there are still some dialects in the districts of these provinces in the Turkish Republic that have not been systematically analyzed. Therefore, we see the need to examine more speech and materials from the dialect data of districts of the provinces, which also allows gathering more recent forms of language use. Due to the technological developments particularly in mass media and the television industry, it becomes much more important to study and compile the characteristics of these living dialects that are understudied empirically in order to capture their linguistic features as they are produced today.

The dialects of the Black Sea Region have attracted many scholars and led to the contributions to the documentation of the characteristics of the folk language spoken in many provinces (e.g., Caferoğlu, 1994; Demir, 2001; Günay, 2003; Korkmaz, 1994). Trabzon, among the northeast provinces, has been considered as an ethnolinguistically enriched province for dialect studies. The Turkish dialects of Trabzon have been extensively analyzed by Brendemoen (2002a, 2002b) and Demir (2006). Their works reflect a good example of structural dialectology and have established the ground for the dialects in the districts of Trabzon province. Although master and doctoral thesis have been written since the 1960s, there are very few relatively contemporary studies with speech collections of today's dialects in the districts of Trabzon (e.g., Öründü, 2001; Çolakoğlu, 2003). Since language is a living phenomenon, an ongoing process of more recent speech collections and analyses can yield to illuminate the possible effects of human interaction and language contact, and thus linguistic transformations or the properties of a language that remain constant.

Brendemoen (2002a) mentioned a major issue of the limited access to female informants because of the social structure of rural parts of Turkey in the 1990s. He believes that 'female informants are (linguistically and generally also in other aspects) more valuable as informants, but much less accessible than the males' (p. 29). Therefore, his data are a compilation of mostly 
male informants in the villages and a few anonymous ladies. Unlike Brendemoen's study, the speech data analyzed in this study is a compilation of female speech, particularly in an open marketplace. In the present study, we observe a phenomenon where women taking the role of a salesperson and involving in work life are encouraged thanks to a bazaar called kadinlar pazarl (women's bazaar) in Akçaabat. Akçaabat is the second biggest district of Trabzon in the $13 \mathrm{~km}$ west of Trabzon that has an area of $385 \mathrm{~km}^{2}$, and the population is 403.851 with the ratio of 56\% female (Akçaabat İlçe Nüfus Müdürlüğü, 2016). In this bazaar, salespeople are provided with the permission to sell the fruits and vegetables that they have produced in their fields. The data of this study was collected from a discourse in the marketplace where the dynamic venues of oral communication and diverse interaction are practiced. Akçaabat dialect has significant phonetic, morphophonological and morphosyntactic deviations from standard Turkish (ST). This study presents the living linguistic characteristics of Akçaabat dialect that are categorized through the codification of the transcribed speech data collected in kadınlar pazarl.

\section{Literature Review}

Turkish dialect research is divided into two periods. First is the late 1860s, the time when international academicians and scientists contributed to the literature, and the second is the 1940s when national scholars began to show interest in the Turkish dialects. The first period where Anatolian dialects gained scholarly attention includes the studies of Maksimov in 1876 on Hüdavendigar ve Karamanlı dialects and Räsänen's preliminary work on regional dialects of Black Sea small and later the essays on Anatolian dialects from 1926 till 1942 (Korkmaz, 1995). On the other hand, Turkish scholars' dialect studies began with Caferoğlu's compilations of the dialects of many provinces in Anatolia in the 1940s for about 20 years that resulted in text collection of nine volumes. Karahan's (1996) pioneering work of classification of Anatolian dialects and endeavor to create the Atlas of Turkish dialects have also been praised for years. Since the 90s, there has been many studies that contributed to the documentation of particular linguistic features of Anatolian dialects and to the quantity and the quality of the compilation of dictionaries such as Compilation Glossary (e.g., Demirci, 2017) and a comprehensive and current bibliographic compilation of Turkey Turkish Dialects Bibliography by Gülensoy and Alkaya (2011).

The Black Sea region has been interesting geography for dialect studies at the provincial and district level. The studies of the north-eastern Black Sea dialects, particularly the dialects of the Trabzon province, often focused on the analysis segmental phonemes, morphosyntactic alterations, syntax at the word and sentential level, and rarely at the lexical level (e.g. Brendemoen, 2002a, 2002b; Çolakoğlu, 2013; Demir, 2006; Tekin, 2002). Besides, Atatürk University has contributed to the research of dialects of Trabzon with master thesis and doctoral dissertations since the 1960s. ${ }^{1}$

1 The theses include the analyses of Sürmene dialect by Aksoy (1963), central Trabzon by Çolakoğlu (2003), Öründü, 2001, and Saphaneli (1973), Araklı by Dilber (1972), Of by Yıldız (1979), and Şalpazarı by Zeytin (1974). 
Caferoğlu (1994) conducted his fieldwork on the classification of the dialects of Turkey including the north-eastern Black Sea dialects. During his investigation that started in the 1940s, he collected speech samples through tales, jokes, folksongs, and similar materials from the informants in 40 provinces. Along with the identification of linguistic characteristics of Anatolian dialects, he also found out that the sound features within the dialects in Trabzon are entirely fixed and systematic, which are linked to the Göktürk and Uygur Turkish. Furthermore, the claim that the migration of Kipchak groups in the Middle Age led to the settlement in the eastern Black Sea region by the Kipchaks (Günay, 2003; Karahan, 1996) is also supported with the similar linguistic features between Kipchak and Trabzon dialects. For example, present tense formation in third person form such as gelúy, yapay (he/she is coming and doing respectively) (Brendemoen, 2002a, p. 225), dative forms of the personal pronouns ben and sen losing the $/ \mathrm{y} /$ and becoming baa and saa that resembles the Middle Kipchak ma: and sa: (p. 265) are features that occur in Trabzon dialects too.

Brendemoen (2002a) created a map of the Trabzon dialects and determined the phonetic, phonological, morphophonological and morphosyntactic differences based on the geographical distribution of Trabzon dialects. Brendemoen (2002b) distinguishes the districts where he collected his speech text data based on the basins that border Trabzon and provides a listing of the districts of Trabzon and their distinctive linguistic characteristics. The conversations that were recorded during the interviews where the informants in many villages of Trabzon told personal stories, war, immigration, and folkloric stories and had casual chats with him led to the building of a map of the dialects. The speech samples revealed variations amongst the districts. This geographical categorization of dialect variations is an elaborate and ambitious work that shows distinct features such as, the use of the allophones of $/ \mathrm{e} / \mathrm{and} / \mathrm{1} /$ in each district.

In Akçaabat surrounded by two basins (The Sera and Kalenima Streams), Brendemoen (2002b) collected speech samples from 1 female (anonymous) and 18 male informants from different villages, which showed phonetic, morpho-phonetic and morphosyntactic features of Akcaabat dialect. Among the salient features is the realization of allophones of many phonemes such as $/ \mathrm{i} /$ and $/ \mathrm{u} /$ and stops and affricates, the violation of vowel harmony, and phonetic changes in the articulation of suffixes. He implies in his book The Turkish dialects of Trabzon that it is the historical background of the region and multilayered structure of settlement in Trabzon that attracted his attention to carry out such an exhaustive analysis of oral collections.

Methodological framework of dialectology includes multidisciplinary approaches and understanding of the context being investigated. The collection of speech, texts, and artefacts requires sufficient knowledge of folklore, history and geography, sociology, and language regarding the dialect area. Corpus-based dialect studies prefer relatively well-preserved units, mostly in villages or small towns, where there has been little communication with the urban surrounding and less technological intrusion (Adigüzel, 2013). One of the essential stages in speech collection is to determine the appropriate compilation techniques and speech events that can elicit the authentic features of a local dialect. Chambers and Trudgill (2004) state for dialect studies, 


\begin{abstract}
"What the linguist is hoping to study in particular is informal speech, not necessarily because it may be more 'normal' - all speakers have both informal and formal styles - but because it is generally more systematic and regular and therefore more interesting than other varieties" (p. 48).
\end{abstract}

Therefore, in qualitative analyses of the corpus of speech data, quality assurance depends on the authenticity of speech that suggests the elimination of environmental and subjective factors to the possible extent.

\title{
3. Methodological Framework
}

\subsection{The Setting: Women's Bazaar}

The open marketplace where the Akçaabat municipality designates particularly for women ${ }^{2}$ is a place where women come and settle every Tuesday at around the same hours. They come from villages of Akçaabat taking the first köy dolmuşu (a type of public transportation) that leaves the village right after prayer time in the morning. The women in the bazaar do not always know each other, yet they look after the stalls or the piece of cloth on which the products are spread in the short absence of each other (see Appendix 1).

Kadınlar pazarı has attracted the attention of people from different income since it is seen as a marketplace where fresh and organic fruits, vegetables and dairy products are promised. The marketplace is a public space where people interact and natural talk occurs, unlike the chain supermarkets where little conversation takes place. Furthermore, the importance of the setting is that the shoppers come from the rural and urban areas of Akçaabat, who are almost exclusively women; thus, we mostly hear women's voices. Other factors in selecting such a research setting are that the use of local language is ensured, it gathers rural and urban settlers together, and the saleswomen are middle-aged and old local people whose dialects are distinctively different from standard Turkish (ST).

\subsection{Data Collection and Analysis}

In this study, the distinctive features of the local dialect of Turkish used in the Akçaabat district in Trabzon are examined with the qualitative-descriptive method. The conversations of women in a bazaar were recorded during three different visits to the bazaar to encode the characteristics of the local dialect under investigation. The bazaar is a public space for shopping where interaction is sustained through (a) exchange of greetings and closings, (b) asking for a specific product, (c) exchange of price information, (d) negotiation, and (e) chat with acquaintances in the marketplace. The conversations were recorded from the openings to the closings for the sake of obtaining complete dialogues when the recording person is mobile going around the bazaar and shopping. $1 \mathrm{~h} 10$ minutes recordings of conversation

2 The bazaar is also open to men to be market vendor and do shopping, yet it is often the case that women dominate the market discourse in this bazaar both for sales and shopping practices. 
were transcribed, and the total corpus yielded 7922 words including fillers. The general noise around the bazaar where there is no focus on a conversation is excluded. Brendemoen's (2002b, pp. 9-11) survey of transcription signs used in the text transcription to present sample speech, yet the corresponding IPA transcription signs are also provided. The text is coded with MAXQDA 2018.2 to measure the frequencies of linguistic features of the local dialect and categories of these deviations from ST emerged. Since the phonetic transcription of the speeches requires linguistically trained ear in the local dialect, two of the participants and two non-participant locals were consulted for the emerging categories with some samples of language produced in the local dialect to provide an emic perspective. $100 \%$ agreement was reached. The emerging categories based on the frequencies of realization of the concerning alteration are presented in Table 1 .

\section{Findings}

The emerging categories include the vowel and consonant phonemic analysis, vowel length as a phonemic factor, deletion of consonants and gerund suffixes, addition of vowels and consonants, the status of present tense suffixes, violation of vowel harmony in ST, use of double verb, and morphological formulation of deixis. Each category presents a systematic analysis of the linguistic features of the local dialect of Akçaabat district.

Table 1: The categorization of the alterations in Akçaabat dialect

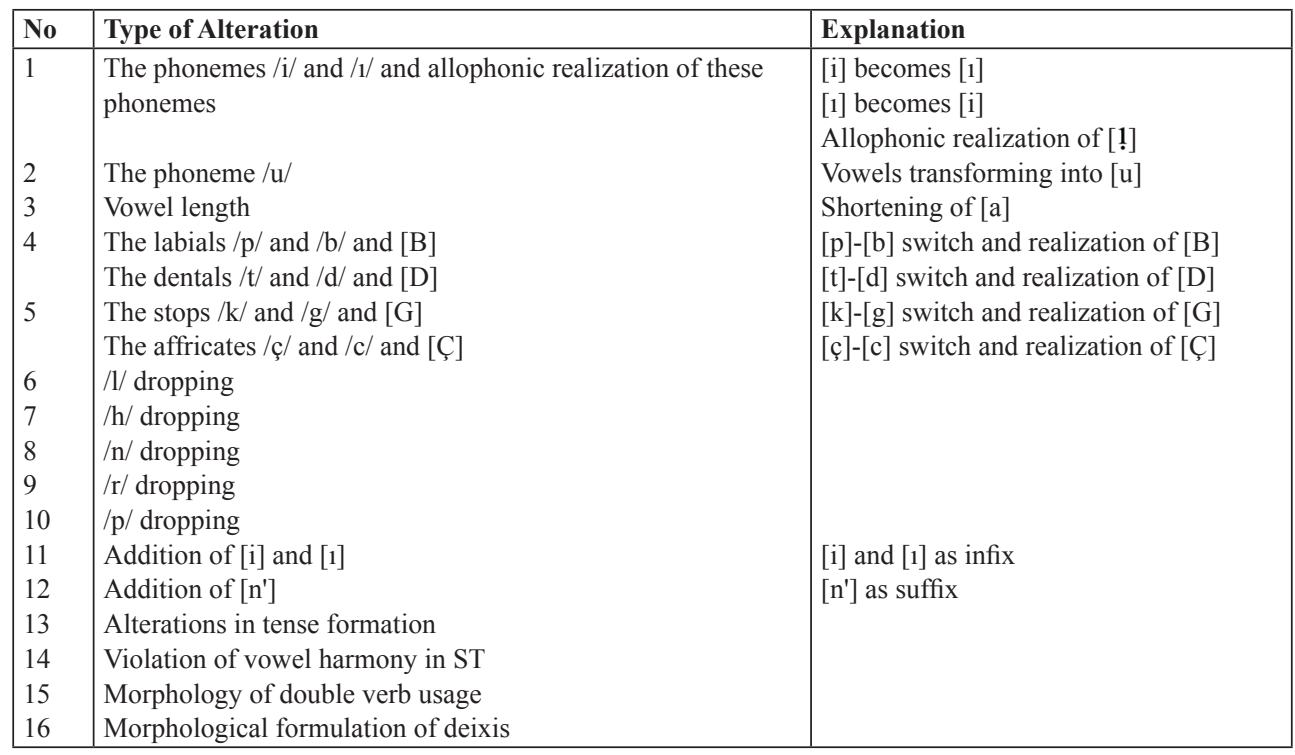




\subsection{The High Unrounded Vowels: The Phoneme /i/ and /1/}

The allophone of $/ \mathrm{i} /$ and $/ 1 /$ that is distinct in the local dialect is [1] corresponding to [i] in IPA, a high central unrounded vowel. The common forms were found in the root of the word as well as in the suffixes. It is a short or half-long vowel that causes vowel backing.

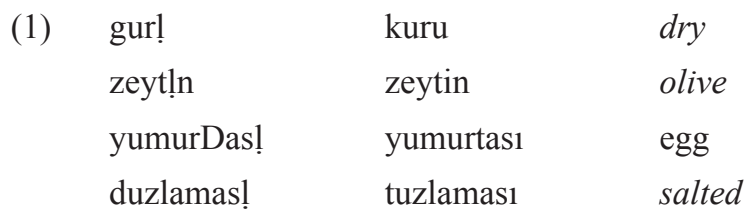

The phoneme /1/ has the allophone [1] that is a high, back unrounded vowel corresponding to [u] in IPA. [1] sound occurs in ST, but the deviation here shows the switch from [i] to [1] in the suffixes.

(2)

$\begin{array}{lll}\text { verelım } & \text { verelim } & \text { let us give } \\ \text { işım } & \text { işim } & \text { my job } \\ \text { kesıld! } & \text { kesildi } & \text { it was cut } \\ \text { bizım } & \text { bizim } & \text { our/ours }\end{array}$

It also shows the switch from back unrounded vowel [1] to front unrounded vowel [i].

(3)

$\begin{array}{lll}\text { onlari } & \text { onları } & \text { them } \\ \text { sardi } & \text { sardı } & \text { s/hewrapped } \\ \text { yanina } & \text { yanına } & \text { near } \\ \text { görmedım } & \text { görmedim } & \text { I did not see }\end{array}$

\subsection{The High Rounded Vowels: The Phoneme /u/}

$[\mathrm{u}]$ is a high, back, rounded, vowel corresponding to IPA [u]. The switch from [1], [i], and $[\ddot{u}]$, which is a high, front, rounded vowel corresponding to IPA [y], to [u] is observed frequently both in the root of the word and the suffixes.

$\begin{array}{lll}\text { (4) içun } & \text { için } & \text { for } \\ \text { kesduk } & \text { kestik } & \text { we cut } \\ \text { k'açau } & \text { kaçağ1 } & \text { the runaway } \\ \text { gaşuk } & \text { kaşık } & \text { spoon } \\ \text { büyusun } & \text { büyüsün } & \text { let it grow } \\ \text { fasulya } & \text { fasülye } & \text { bean }\end{array}$




\subsection{Vowel Length}

Lengthening the vowel with zero realization of consonants are not exceptions.

(5) l'a:na

lahana

cabbage

On the other hand, we observe systematic shortening of the vowels in words like;

(6)

$$
\text { cezaevi ceza:evi jail }
$$

\subsection{Phonemic Analysis of Obstruents}

As a common characteristic across Trabzon dialects, Akçaabat dialect also operates on the switch of the voiced and unvoiced quality of stops and affricates.

[B] is an unaspirated unvoiced labial stop (IPA [p]) that is quite distinctive in Akçaabat dialect. It often replaces the [p'] that has an aspiration and [b] that is not aspirated but voiced. Frequent examples are as follows.

\begin{tabular}{|c|c|c|}
\hline Bazardan & pazardan & from the bazaar \\
\hline Baz1 & pazı & chard \\
\hline
\end{tabular}

We also observe the commonly-referred characteristics of Trabzon dialects $\left[\mathrm{p}^{ }\right]$- $[\mathrm{b}]$ in the following examples more frequently than [b]- [p'] such as pozuluy (going off-for food).

(8)

$\begin{array}{lll}\text { ebiy } & \text { epey } & \text { quite } \\ \text { sebeD } & \text { sepet } & \text { basket }\end{array}$

[D] is a dental stop that has unaspirated and unvoiced quality (IPA [ $\mathrm{t}]$ ). This stop is marked for Akçaabat dialect. It causes the loss of aspiration yet does not quite make a voiced stop.

$\begin{array}{lll}\text { Doumi } & \text { tohumu } & \text { the seed } \\ \text { düDün } & \text { tütün } & \text { tobacco }\end{array}$

More distinctively, the marked [ $\left.\mathrm{t}^{\prime}\right]-[\mathrm{d}]$ alternation is observed in the data such as;

$\begin{array}{lll}\text { tikanda } & \text { dükkanda } & \text { at the shop } \\ \text { fiyad! } & \text { fiyatı } & \text { the price }\end{array}$

$[\mathrm{G}]$ is an unaspirated unvoiced velar stop (IPA [k]) that is realized in the following examples.

$\begin{array}{lll}\text { (11) farGetmez } & \text { farketmez } & \text { it doesn't matter } \\ \text { şüGür } & \text { şükür } & \text { thank God }\end{array}$

As for the marked [ $\left.\mathrm{k}^{\prime}\right]-[\mathrm{g}]$ alternation where aspiration disappears and the vowel in the syllable gains a voiced quality, we observe the following examples. 


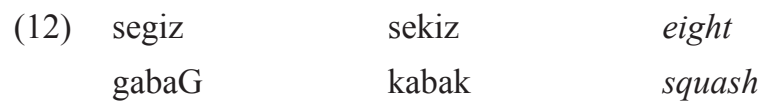

Apart from the stops, the affricates /ç/ and /c/ have a rare allophone /Ç/ that is marked in the local dialect. $/ \mathrm{C} /$ is a variant of $/ \mathrm{d} z /$ that "the voice onset time after the release is somewhat longer than for /c/' and the sound is softer than /ç/.

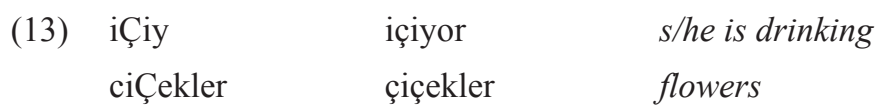

There are also examples of consonant alternation from the unvoiced palate-alveolar affricate [ç] (IPA [tf]) to the voiced palate-alveolar affricate [c] (IPA [dz]) as in the following examples.

$\begin{array}{lll}\text { (14) ac1yorum } & \text { aç1yorum } & \text { I am opening } \\ \text { acuk } & \text { azcık } & \text { a little }\end{array}$

\subsection{Deletion of Consonants: /l/, /h/, /n/, /p/, and /r/}

The deletion of $/ 1 /, / h /$, and $/ \mathrm{n} /$ causes elongation of the vowel in the preceding syllable. The place of dropping these sounds does not seem quite systematic. Several examples can be as follows.

$\begin{array}{lll}\text { o:sun } & \text { olsun } & \text { let it be } \\ \text { k'arnlba:rlari } & \text { karnibaharları } & \text { the cauliflowers } \\ \text { ba: } & \text { bana } & \text { to me }\end{array}$

The deletion of $/ \mathrm{r} /$ has two forms. If the deletion is realized in the root of the word, it is in the coda position unless it is a one-syllable word. If the deletion is in the suffixes, it can be in the nucleus or coda position.

$\begin{array}{lll}\text { gada } & \text { kadar } & \text { amount } \\ \text { bunla } & \text { bunlar } & \text { these } \\ \text { galdidım } & \text { kaldırdım } & \text { I lifted }\end{array}$

Finally, the deletion of [p] is only observed in the verbal suffix (I)P exclusively.
(17) alı gelırım
alıp gelirim
I fetch

\subsection{Addition of Vowels and Consonants: [i], [1], and [n']}

Although a few occurrences can be listed in the present corpus, [i] and [1] addition in the nucleus position is observed whereas [n']addition exclusively occurred when the postposition ile (with) is suffixed to the word. 


\begin{tabular}{|c|c|c|c|}
\hline \multirow[t]{2}{*}{ (18) } & Keziban & Kezban & a female name \\
\hline & abilan & ablan & your elder sister \\
\hline \multirow[t]{3}{*}{ (19) } & paralan' & parayla & with money \\
\hline & garisilan' & karısıyla & with the wife \\
\hline & onlan' & onunla & with him/her/it \\
\hline
\end{tabular}

\subsection{Suffixes for the Tense Formation}

Trabzon dialects have used the contracted forms of the present (continuous) tense suffixes, and Akçaabat dialect is among the ones adopting the contracted form systematically for each pronoun.

\begin{tabular}{|c|c|c|}
\hline (20) gidiyrım & gidiyorum & I am going \\
\hline bakaysın & bakiyorsun & you are looking \\
\hline diy & diyor & s/he is saying \\
\hline
\end{tabular}

We observe a rare case where the suffix for the pronoun we deviates from ST entirely in the formation of present tenses as well as future tenses. Apart from the contraction, $[\mathrm{z}]$ in the coda alters and becomes [k]. However, past tense formation with we follows ST with the consonant in coda, though the contraction is still realized.

$\begin{array}{lll}\text { öğretiyruk } & \text { öğretiyoruz } & \text { we are teaching } \\ \text { gatayruk } & \text { katıyoruz } & \text { we include } \\ \text { gidecu:k } & \text { gideceğiz } & \text { we will go } \\ \text { bilmiyduk } & \text { bilmiyorduk } & \text { we didn't know }\end{array}$

\subsection{Vowel Harmony Violation}

ST has a symmetrical system with vowel harmony where roots do not change, and the affixes agree with the category of the nearest vowel. However, we observe that most of the examples above that vowel alterations are realized both in roots and affixes exemplify a disharmony, that is, vowel harmony violation in the dialects of Trabzon. Therefore, many examples of vowel alterations that happen in the root and suffixes have fallen into this category as well. In the present data, the violation of palatal harmony drives from frontalization of [1] and occasionally $[\mathrm{u}]$ and backing of [i] and [ü]. Among these deviations, the fronting of [1] and backing of [i] are apparent in the data and exercised more.

$\begin{array}{llll}\text { (22) Frontalization } & \text { kabalida } & \text { kapalıda } & \text { in the closed } \\ & \text { buni } & \text { bunu } & \text { this } \\ \text { Backing } & \text { geldınız } & \text { geldiniz } & \text { you came } \\ & \text { yuzunden } & \text { yüzünden } & \text { because of }\end{array}$


Furthermore, the vowels such as the allophones of /1/ and /a/ such as [1] (IPA [i]) and [ä] (IPA [æ]) that occur in Akçaabat dialect must be approached with delicate care in terms of vowel harmony violation.

Finally, the corpus demonstrated that the vowel alterations influenced more than vowel harmony in words. It also affected the agreement of question particle forms of 'mi' and the adverb 'da' that means 'too' such as var mi? (var m1? in ST=is there?) and geline da (geline de in $\mathrm{ST}=$ to the bride too).

\subsection{Double Verbs}

In the formulation of double-verb usage, the verb is doubled with its nominalized form in the affirmative sentence structure whereas, in the question form, the particles mi and $\mathrm{m}$ are placed in the between (e.g., 23b). Since -me and -ma are the only particles to make a noun out of a verb in the bare form (due to -mek and -mak attached to the bare form of verbs), the question particles only occur in the form of mi and $\mathrm{mi}$.
a. sorma sordum
sordum
I asked
satma satti
satt1
he sold
b. alma mi aldın
aldın mi
did you buy

\subsection{Morphology of Deixis}

The data provided evidence of morphologically differently constructed deixis quite often in the data. The particle 'ha' is attached to the word and becomes the first syllable. It occurs in front of the spatial and temporal deictic expressions in the form of demonstratives, pronouns, adverbs of time and place. We also see a single form of discourse deixis that points to the speaker's current state referring to the prior part of the discourse. These formulations can be exemplified as follows:

(24) Spatial deixis

habın!, habı, habı(n)larl, hau, habırda, habınla, habırlye, haurdan, haunda, haunlar

(a) A: yumurta ne gadar yumurta ne kadar (How much is the egg?)

B: yumurta iki lira habı abılamındı ama benım köylümdu o yumurta iki lira bu ablamındır ama benim köylümdür o (The egg is two liras. It is my sister's here but she is my fellow townswoman.)

A: heea şiy tanesi bi lira hee şey tanesi bir lira 
(Hmm, well, one is a lira.)

B: he: al haunlari on cift var haunda al oni evet al onlarl on çift var onda al onu (yeah, take them, there is a dozen there, take it.)

A: heea yoo sorma sordum sadece hee yok sordum sadece (oh well, I am just asking.)

Temporal deixis haşindi, haşindiye (şimdi, şimdiye $=$ now, till now)

(b) çok güzel' haa haşindi bu saba kesti onlari çok güzel haa şimdi bu sabah kesti onları (It is very good, she has cut them now, this morning.)

(c) seni bekleduk haşindiye gada seni bekledik şimdiye kadar (We have been waiting for you till now.)

Discourse deixis haule

(d) A: ...geldınız pazara he ...pazara geldiniz öyle mi (You have come to the bazaar, haven't you?)

B: neabalim ne yapalim (nothing unusual)

A: nassin na:ber nasilsin ne haber (How are you? What's new?)

B: i: nossun haule iyi ne olsun öyle işte (Fine. Same old. So it is.)

\section{Discussions and Conclusions}

In the study, the deviations in the local dialect of Akçaabat that is located in the Trabzon province were interpreted with reference to standard Turkish. Such an approach to interpretation should not be taken as an erroneousness. On the contrary, it is the richness of the local dialects and may even be the essence of a language. When the languages of Oghuz and Old Anatolian Turkish effect on the dialects of Trabzon upon migrations are taken into consideration, it is 
not always possible to provide systematic evidence of whether what we refer as alterations or deviations from ST today are indeed deviated or remained constant.

The study investigated the Akçaabat district, which is understudied, through the collection of woman speech. The findings demonstrate that there are middle sounds both with consonants and vowels in addition to the sounds of ST. This finding is echoed in Brendemoen (2002a, 2002b) and also in Çolakoğlu (2013) who reported 12 vowels and 15 consonants in Trabzon dialects that are additional to the eight vowels and 21 consonants in ST.

It is seen that $/ \mathrm{i} /$ and $/ 1 /$ phonemes often appear to replace each other, and the allophone $[\mathbf{1}]$, that is neither [i] nor [1] sound is frequently produced in the center of the mouth. [1] $]$ is observed to be a distinctive sound in the local dialect. Similarly, the data show that $/ \mathrm{u} /$ is also transformed. Brendemoen (2002b, p.187) also provides examples of such transformations with funduuni (its nuts)and verur (it gives) in his speech collection data from Akçaabat district. The vowel length with certain words such as cezaevi (jail) shows consistency, and the length remains constant in each utterance time.

It is observed that the $/ \mathrm{p} /-/ \mathrm{b} /, / \mathrm{t} /-/ \mathrm{d} /, / \mathrm{k} /-/ \mathrm{g} /$, and also $/ \mathrm{ç} /-/ \mathrm{c} /$ displacement that is documented to be a salient feature in the Trabzon dialect studies (Brendemoen, 2002a; Coşar, 2015) is apparent and frequent in the local dialect of Akcaabat. The most noteworthy case is that the realization of $/ \mathrm{G} /, / \mathrm{B} /, / \mathrm{D} /$, and also /Ç/ sounds that are produced between the two sound pairs. Losing the aspiration in the voiceless consonants, these unaspirated and unvoiced sounds can be produced in onset, nucleus, and coda positions. In align with this finding, Brendemoen (20021) states that one of the main characteristics of Trabzon dialects is that the stops have a voiced onset time that is shorter than the unvoiced aspirated stops but longer than the voiced ones. The dialect of the district in this sense is similar to the sound production of other districts in Trabzon.

We also encounter a systematicity with the dropping and addition of sounds. Such alterations as the vowel elongation when $/ \mathrm{h} /$ is dropped, dropping of $/ \mathrm{p} /$ in the formulation of verbal adverbs, and [n'] addition in coda position when the ile (with) in the attached form in Turkish is used show structural systematicity and prominent features of the dialect. There are similar findings in Öründü's study (2001) of Akçaabat dialect regarding the consonant dropping, though his data revealed further droppings of / $\breve{\mathrm{g}} /, / \mathrm{t} /$, and $/ \mathrm{v} /$. Furthermore, we observe other regularities with morphological forms. Structural differences in the tense formulations and alterations of sounds that violate the vowel harmony in the dialects of Trabzon are expressed as common features. Concerning the double verb usage in the dialect, Coşar (2015) asserts that using double verbs is considered to strengthen the meaning. It appears that these characteristics recur in the dialect of Akçaabat as well as Trabzon.

Lastly, the 'ha' particle attached to the deictic expressions appears to be a prominent quality of the deixis in the dialect. The present data show that the deixis point to space, time, and discourse that complements the contexts of an utterance with 'ha' particle. The meaning 
it adds to the deixis should be further investigated; however, it seems that 'ha' adds a sense of pointing, momentarily move, and grabbing attention prior to the deictic expression to be used. It stands out to strengthen the meaning retained in the deictic expressions.

It is essential to examine the speech events that take place in public for the dialect studies to collect naturally occurring speech. This study allows us to hear the dialectal speech of women from the villages of Akçaabat that we encounter as market vendors in a marketplace in the urban area. We believe that it is a relevant approach to examine the speech of woman that is considered to be a linguistically valuable resource, as Brendemoen (2002a) argued. However, this study does not intend to compare the speech of men and women linguistically. Nevertheless, when we carefully look at Brendemoen's work decades ago with men's speech in the same region, the findings of this study show similar sound qualities and variations in the dialect in terms of men and women's speech. Besides, this study can provide a glimpse into the range of variation that the dialect of Akçaabat has kept unchanged since Brendemoen's valuable work regardless of gender. We believe that this particular data provided a snapshot of representative dialectal features of the time of writing and contributed to the corpus of regional dialects. The continuity of these types of studies through recent and natural speech samples and analysis of the data collected in different speech events is significant in order to demonstrate variations and transformation of the living dialects of a language.

Acknowledge: I would like to thank Sema Misir who supported me during my data collection process with regard to the access to data in the region.

Peer-review: Externally peer-reviewed.

Conflict of Interest: The author has no conflict of interest to declare.

Grant Support: The author declared that this study has received no financial support.

Teşekkür: I would like to thank Sema Mısır who supported me during my data collection process with regard to the access to data in the region. XXXXXX TR

Hakem Değerlendirmesi: Dış bağımsız.

Çıkar Çatışması: Yazar çıkar çatışması bildirmemiştir.

Finansal Destek: Yazar bu çalışma için finansal destek almadı̆̆ını beyan etmiştir.

\section{REFERENCES/KAYNAKÇA}

Akçaabat İlçe Nüfus Müdürlüğ̈̈. (2016). Retrieved April 27, 2019, from http://www.akcaabat.gov.tr/ ilce-nufus-mudurlugu

Adıgüzel, A. (2013). Dünyada ve Türkiye Türkçesinde ağız çalışmaları ve yöntemler. Electronic Turkish Studies, 8(9), 387-401.

Brendemoen, B. (2002a). The Turkish dialects of Trabzon: Their phonology and historical development (Vol 1). Wiesbaden, Germany: Otto Harrassowitz Verlag.

Brendemoen, B. (2002b). The Turkish dialects of Trabzon: Their phonology and historical development (Vol 2). Wiesbaden, Germany: Otto Harrassowitz Verlag. 
Caferoğlu, A. (1994). Kuzeydoğu illerimiz ağızlarından toplamalar. Ankara, Turkey: TDK Publishing.

Chambers, J. K., \& Trudgill, P. (1998). Dialectology. Cambridge, UK: Cambridge University Press.

Çolakoğlu, B. K. (2003). Trabzon ağzı. (Unpublished master's thesis). Niğde University, Niğde, Turkey.

Çolakoğlu, B. K. (2013). Ağız çalışmalarının önemi ve Trabzon ağız özelliklerinin değerlendirilmesi. Journal of World of Turks, 5(3), 207-221.

Coşar, A. M. (2015). Bir kimlik işaretleyicisi olarak dil ve Trabzon ağızlarında arkaik hususiyetler. Karadeniz Araştırmaları Enstitüsü Dergisi, 1(1), 241-253.

Demir, N. (2001). Ordu ili ve yöresi ă̆ızları. Ankara, Turkey: TDK Publishing.

Demir, N. (2006). Trabzon ve yöresi ă̆ızları. Ankara, Turkey: Gazi Press.

Demirci, M. (2017). Derleme Sözlügü̈'ne Osmaniye, Düziçi Ağzından Katkılar -I. Uluslararası Türkçe Edebiyat Kültür Eğitim (TEKE) Dergisi, 6(3), 1360-1383. Retrieved from http://dergipark.org.tr/teke/ issue $/ 31471 / 344445$

Gülensoy, T. \& Alkaya, E. (2011). Türkiye Türkçesi ağızları bibliyografyası (2nd Ed.). Ankara, Turkey: Akçă̆ Press.

Günay, T. (2003). Rize ili ă̆ızları. Ankara, Turkey: TDK Publishing.

Karahan, L. (1996). Anadolu ağızlarının sinıflandırılması. Ankara, Turkey: TDK Publishing.

Korkmaz, Z. (1994). Bartın ve yöresi ă̆ızları. Ankara, Turkey: TDK Publishing.

Korkmaz, Z. (1995). Anadolu ağız araştırmalarına toplu bir bakış: Türk dili üzerine araştırmalar (Vol 2). Ankara, Turkey: TDK Publishing.

Öründü, F. (2001). Trabzon ve yöresi ağızlart. (Unpublished master's thesis). Karadeniz Technical University, Trabzon, Turkey.

Tekin, F. (2002). Trabzon ve yöresi ağızlarının etnik yapı ile ilişkisi. Proceedings of International History, Language, and Literature Symposium: Trabzon ve Çevresi (Vol 2) (pp. 195-201), Trabzon, Turkey: Trabzon Municipal Press.

Uysal, N. İ. (2009). Karaman ili ağızları ve Anadolu ağızları arasındaki yeri. (Unpublished doctoral dissertation). Pamukkale University, Denizli, Turkey. 
Appendix 1. An outlook to the women's bazaar

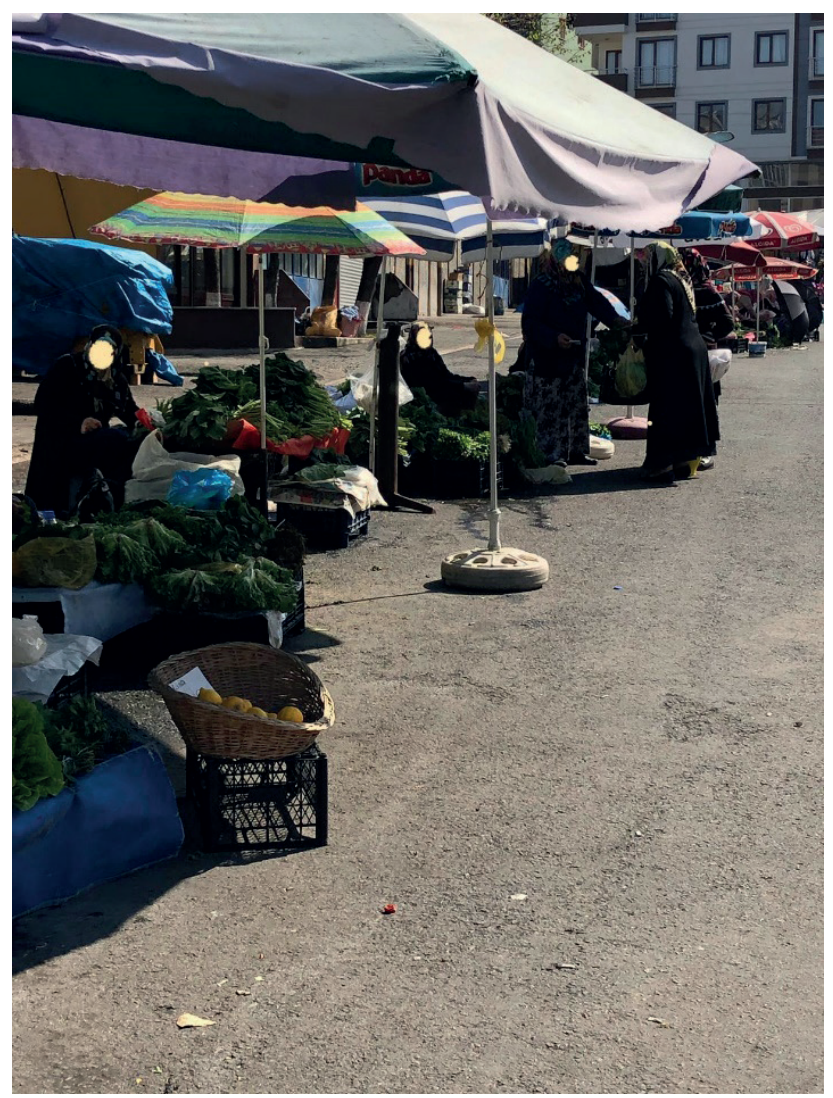

